\title{
The implication of bilingualism in EFL classroom: An investigation of teaching and learning in English department
}

\author{
Chairuddin Chairuddin ${ }^{1}$, Maulana Yusuf Aditya ${ }^{2}$, \\ 1,2English Education Department, STKIP PGRI Bangkalan, Indonesia \\ ${ }^{1}$ chairuddin@stkippgri-bkl.ac.id, 2aditya@stkippgri-bkl.ac.id \\ *) correspondence: chairuddin@stkippgri-bkl.ac.id
}

\begin{abstract}
Bilingualism is used as a cover term for multilingualism, too - speaking more than two languages. Some researchers use the term plurilingualism for speaking more than two languages. few bilinguals are as proficient in any second language as they are in their first language. This research aims to determine the implication of bilingualism in EFL classroom. Descriptive qualitative is used as a research approach and its application uses phenomenology methods. The findings showed that the implication of bilingualism to students' speaking. The implication is about interact and apply the lecturer' utterance. It can be said this implication related to the students' understanding of the word meaning in speaking. Second implication from the observation data is about students' comprehension in a certain word, such as compounding. The lecturer used bilingualism to explain the meaning of the word. By using Bahasa, the students were easier to understand the lecturer statement. In this case, the students knew what the lecturer' uttered and finally they could know the meaning of the word.
\end{abstract}

Keywords: bilingualism; implication; EFL classroom; teaching and learning

\section{INTRODUCTION}

According to Lambert (1981), when individuals in a minority group learn a second language, it is likely to replace their first language. In contrast, when individual in the majority group learn a second language, they become bilinguals. The former is called subtractive bilingualism and the later is additive bilingualism. The social context results in either of the two situations. A large number conducted in Canada have supported the hypothesis. Therefore, it is important to consider the social context where a study is conducted to examine the effect of bilingualism. Myers-Scotton cites that bilingualism is the term for speaking one or more languages. Usually the speakers' mother tongue or first language is one of the two languages that make them bilinguals. Bilingualism is used as a cover term for multilingualism, too - speaking more than two languages. Some researchers use the term plurilingualism for speaking more than two languages (2006: 02). In the other words, Myers-Scotton adds that few bilinguals are as proficient in any second language as they are in their first language. And, if they do speak several second languages, they generally do not speak all of them equally well. There are two socially based main reasons: (1) Few bilinguals have been equally exposed to all languages in their repertoire and (2) They don't use them with the same frequency or in the same situations (2006: 03).

In a social interaction, each speaker has ability and competence to change a language by giving more attention in a social context where the language grows and improves. The contextual differences will give a different language. Traditionally, we use language to communicate and interact each other. In that case, we try to convey our mind, point of view, idea, concept and feeling based on the nature law that we are the social creature and have many differences with other. Many language learners regard speaking ability as the measure of knowing a language. These learners define fluency as the 
ability to converse with others, much more than the ability to read, write, or comprehend oral language. They regard speaking as the most important skill they can acquire, and they assess their progress in terms of their accomplishments in spoken communication. Teachers should create active learning condition and develop their technique to help learners communicate more effectively by considering suitable activities for each group of learners. The most teachers aim is making their students able to communicate and convey information effectively in spoken English. Besides, the teachers should create active learning condition and develop their techniques. As we know, there are many languages in the world such as English.

In Indonesia, English is not only has become a language for certain people, but also for common people and it is a subject which has been taught formally to Indonesian students since they are in kindergarten school. English consists of four skills such as listening, speaking, reading, and writing. Speaking skill has become the first priority to be taught between the four skills since communicative approach implementation has been influential in foreign language learning. It is based on instruction goal of English Department curriculum in STKIP PGRI Bangkalan. Speaking ability is an important thing in the process of language learning. We communicate through our oral expression to gain much more information effectively and efficiently. The teacher should be aware of the students' speaking ability because it influences much to other students' success in language learning. The ability to speak a foreign language is with no doubt become the mostly highly prized language skill.

\section{METHODS}

In conducting this research, researchers used a qualitative descriptive research approach and phenomenological method as its application. Therefore, researchers focus more on text analysis obtained from observations in the form of field notes. The researcher explained how the research was conducted. Forms, functions, factors, linguistics form, in the EFL classrooms were explored in the boundary of case study research. Yin cites that case study research can be based on qualitative or quantitative evidence or mix of them. It brings the flexibility to the researcher to choose the best research approach for this research (2003: 15). The researcher focused on qualitative research related to the problems arises from the EFL classrooms. The first discussion in this chapter was started with the discussion of setting of the research. The second described about research strategy. The third was extended by data sources. The fourth discussed about technique of collecting data. The fifth of the discussion took a part on trustworthiness. Finally, this chapter widely explored about technique of analyzing data.

\section{RESULTS AND DISCUSSION}

This part provides the explanation of the findings dealing with bilingualism in teaching learning process in speaking class. In this research, the findings are divided and presented based on the problem statements as follows: (1) description of the lecturer's bilingualism within the EFL classrooms, (2) the description of the students' bilingualism, and (3) the description of the implication of bilingualism to the students' speaking achievement in English.

\section{Lecturer's bilingualism within the EFL classroom.}

Dealing with teaching learning process of EFL classroom, the researcher found several aspects related to the bilingualism of the lecture in that situation. Those are: (1) form, (2) function, (3) situation or factor (4) linguistic aspects, and (5) frequency bilingualism, which are summarized in table 4.1. In more detailed, each of the findings related to the lecturer's bilingualism is described in the following discussion.

\section{a. Forms of bilingualism}

As was explained in chapter 2, there are three different types of bilingualism: intra-sentential, intersentential and tag-switching (Poplack 1980). In the following, the present data were analyzed according to these three types. This analysis served as a starting point to the later analysis of the functions of bilingualism.

(1) Intra-sentential 
Intra-sentential bilingualism occurs within a sentence. According to Poplack (1980), it requires a lot of integration and therefore it is only used by the most fluent bilinguals. This type of BILINGUALISM occurred when the conversation happened in the classroom. The lecturer started to make a small talk to stimulate the students' class in speaking. The example of intrasentential BILINGUALISM here occurred in translating a word.

Example 1:

L: So please try to ask your teacher the synonym of the word of undertake, please check the meaning. It does not mean under and take mengambil dan di bawah, berarti artinya mengambil yang dibawah, tidak.

S: the meaning is menjalankan.

$\mathrm{L}$ : menjalankan? $\mathrm{Ok}$, undertake is menjalankan

This form is very common in that situation, because in certain word sometimes students get problem with the meaning. Therefore, the lecturer asked the students about the English word in Bahasa. When she inserted bilingualism, she tried to translate the word. The researcher treated this instance as intra-sentential since the switching takes place within a sentence.

\section{(2) Inter-sentential}

Inter-sentential bilingualism occurs between sentences or clauses, or between turns. The data is used in the classroom activity. It happened to clarify the utterance to the students or even to translate.

Example 2:

L: this is free speaking. So sorry, I have to ask you to copy this book. It talks about culture. You will spend for about fifteen thousand. Come on, give me some suggestions and advices in order to make you easier to understand my speaking. jadi bahasa inggris macam apa yang harus saya gunakan.

S: you can use bahasa tubub ha ha ha

Example 2 shows how inter-sentential bilingualism is used within the speaking class. The situation there was learning about speaking activity and the lecturer tried to make easier way in giving instruction. She used English at the first conversation to start the class. And then for the next utterance she applied bilingualism that it is categorized as inter-sentential. This text happened to clarify the speaking style used by the lecturer. We can see on the text of English switched to Bahasa that the place where the sentence begins is marked with pause. The speaker used pause when she switched from English to Bahasa.

The pause is good indicator of the beginning of a new sentence or clause, since in spoken discourse the boundary between two sentences or clauses are not always clear. The speaker usually has little pauses in the turn, which in everyday conversation could indicate to the other participants that they could self-select to be the next speaker. In a classroom, however, the lecturer usually allocates turns; the students know this which means that they do not necessarily start speaking whenever there is a pause. Moreover, in example 2 the students wait for the lecturer to tell them to respond the lecturer's utterance.

Inter-sentential bilingualism can also occur between turns. In such a case the previous turn is in language $A$ and the following in language B. In example shows how inter-sentential bilingualism is employed between turns. This example is from the speaking class students and here the class is having a discussion about speaking material.

\section{(3) Tag-switching}

Tag-switching means inserting a tag in one language to an utterance that is otherwise in another language. In classrooms this means that while speaking English the lecturer can insert a language tag to the utterance, or vice versa. Furthermore, a tag can be moved freely in a sentence, they do not have syntactic constraints. Tag-switching occurred in this classroom, but there are only a few instances of it there.

Example 3: 
L: undertake? itu types of phrasal word, ya. Jadi undertake, understand and others. That's so difficult actually. So please try to ask your teacher the synonym of the word of undertake, please check the meaning.

Tag-switching is quite rare in the data. Usually when there is switching within a sentence, it is intra-sentential switching which means that the insertion requires knowledge of both the languages. Tag-switching, on the other hand, only occurs in cases like in example 3. However, the researcher saw that tag-switching is merely tags such as you know or yes and usually consisting of one or two words.

\section{b. Function of bilingualism}

The focus of this discussion is to report different functional categories that were found in the data. The functions here related to the switching of the lecturer during the learning process.

\section{(1) Explanation.}

Explanation occurs when (usually) the lecturer wanted to repeat what had been previously said in another language in order to help the students' understanding. In EFL classroom, this explaining generally happens in L1, the mother tongue of the students (Bahasa in the present data), since they are less competent in the foreign language and may need an explanation to help them to understand the lesson better. In the present data, explanation is a common function of bilingualism; it occurred in the class during the learning.

Example 4:

L: this is free speaking. So sorry, I have to ask you to copy this book. it talks about culture. You will spend for about fifteen thousand. Come on; Give me some suggestions and advices in order to make you easier to understand my speaking. jadi bahasa inggris macam apa yang harus saya gunakan. S: you can use bahasa tubub ha ha aha

L: just give it body, I know, I know. And than for the language vocabnya asing miss. So, could you give me example what kind of vocabulary that you can't understand. contoh vocab yang tidak dimengerti. Just remember the vocab that you could not understand.

S: undertake miss.

The conversation between the lecturer and students above happened because the lecturer asked the students to give suggestion about her speaking. The reason is to make the students easier in understanding the lecturer's utterances. At first line of the words, the lecturer used English in conveying her idea. Yet, the students did not reply her speech. After she inserted or switch her language to bahasa, jadi bahasa inggris macam apa yang harus saya gunakan, one of the students gave a comment.

(2) Interpreting subject matter

It commonly happened when the students get misunderstanding of a word meaning. In that reason, the lecturer switched her language to Bahasa. She often switched their code to translate or elaborate the important message during the process of explaining new vocabulary, grammar points or instructions instead of continuing in the foreign language. It reduced the comprehension burden and made it easier for students to focus on the important message conveyed. The following example showed the translation function of bilingualism was conducted by the lecturer.

Example 5:

S: undertake? itu types of phrasal word, ya. Jadi undertake, understand and others. That's so difficult actually. So please try to ask your teacher the synonym of the word of undertake, please check the meaning. It does not mean under and take mengambil dan di bawab, berarti artinya mengambil yang dibawah, tidak.

$\mathrm{S}$ : the meaning is menjalankan

$\mathrm{L}:$ menjalankan? Ok, undertake is menjalankan

The researcher found the utterance from the lecturer that could be indicated as interpreting subject matter function. In this case the text, mengambil dan di bawah, berarti artinya mengambilyang dibawah, tidak", appeared when the lecturer gave explanation of a word meaning. So, to make the students understand about the word, she inserted that code to her utterances. 


\section{(3) Giving instruction}

It usually happened in the situation when the students did not know well about the point of lecturer's wants. Generally, it could be from the lack of word when the lecturer used English to give instruction. Therefore, she applied her language to bahasa to guide the students in a good direction of learning activity. The example of that situation is shown below. Example 6:

L: So, guys please say your word and give your opinion in English and you can switch in Indonesia but not always, based on your knowledge. Come on!

S: you meet someone and have fun together. He gives you his phone number. What do you do?

S: forget to phone them

L: loh ndak, it's your answer, your own answer. You read your answer. And then, score your answer based on your sheet.

S: owww, our answer. Ok!

L: baca jawabannya saja.

The lecturer wanted to convey appropriately to the students. The words lob endak appeared because at that time the student answered the question which red by another student. So, the lecturer told her not to answer it. While the utterance baca jawabannya saja appeared because the student red all of the questions. So, the lecturer told her to read the answer only by using Indonesian in order that she understood what the lecturer supposed.

(4) Managing the class.

The lecturer sometimes used bilingualism to manage the situation of the class. She used it as one of the strategies in making the students to pay attention more about the topic discussed. Example 7:

L: ob ya, Nuriman sorry. And than, ke sayimah, kembali ke sayimah back to Sayimah. I ask you to think and speak up. So, submit your brain, pick your brain. So, ada apa denganmu, kenapa harus menghilang? because of your teacher or yourself. You have to think that I'm the clever person in the class. Don't you think so?

S: what miss?

$\mathrm{L}: \mathrm{I}$ 'm the clever person in the class. Why because I'm teaching.

The conversation above conducted in the classroom during the small talk between the lecturer and the students. In the first text, the lecturer talked about a student namely Nuriman, in that situation most of students made a little conversation among them. They did not pay attention the lecturer utterances. The lecturer realized about the condition of the class. For that reason, she changed the topic of discussion and went to another by inserting bilingualism ke sayimah, kembali ke sayimah. She used it to trig the students' attention or to manage the classroom. After all, all students stopped their conversation and gave their mind back to the lecturer's words.

\section{(5) Asking the word meaning.}

It can be realized that the lecturer is native speaker of Indonesia. Rather than true bilinguals she is monolingual individual who have skills and knowledge in the target language. It is possible due to this reason that they sometimes cannot recall the required target language word especially at the moment of utterance. This situation truly represents the context of teaching situation. The conversation below showed us about lecturer's bilingualism in asking a word meaning in English.

Example 8:

S: kurang tegas itu apa?

L: What we say tegas in English? Aabh, $O k$, that's why I remind you to bring your dictionary.

S: tegas

S: Clear.

L: Ok! Clear. Don't bring that one. But you have to bring The Oxford Dictionary.

From the text above we know that the lecturer asked English word of tegas. Yet, it does not mean that she did not understand the meaning. She only wanted to make sure the students' 
comprehension or understanding in words. The word tegas appeared from the student's conversation. And then, the lecturer asked other students.

\section{(6) Checking understanding}

Part of the foreign language learning process is to learn new words and expressions. The material is there to help this process; the students have chapters to read and exercises to do which teaches them new vocabulary. In the teaching situation, when the class is, for example, doing an activity in English, the teacher should make sure that all students know all the words in that activity. If there are new words or expressions, the lecturer can ask them what they mean in Bahasa. In other words, the lecturer does not have to translate everything. By asking the students, she lets them participate more actively to the lesson. bilingualism occurred when the word or expression is translated into Bahasa, or when the lecturer asked about the new vocabulary in Bahasa.

\section{c. Situation or factor of bilingualism}

In determining the factor of the lecturer's bilingualism, the researcher conducted interview. From the data of interview found that the lecturer was affected some reasons or factors in applying bilingualism in EFL classroom. The factors related to the students' comprehension, change of topic, policy of institution or English department, and personal factor dealing with attendance.

\section{(1) Students' comprehension}

The lecturer argued that the students have different character and comprehension in language. A few of them were still confused in language proficiency related to certain or uncommon words. Therefore, it was really needed for her to conduct bilingualism in her class of speaking. The following text is the short interview of the researcher and the lecturer.

\section{Sometimes I use bilingualism related to the students' comprehension. Because I know that some students are still in low level of English or they are not able to speak English well (interview).}

The data from interview here has relation with the observation applied by the researcher. It was found in data of observation that one of the functions in lecturer's bilingualism was explanation. It occurred when the lecturer wanted to repeat what had been previously said in another language in order to help the students' understanding of the lesson or the lecturer's explanation. This factor is a common in the class during the teaching learning process.

\section{(2) Topic change}

Another factor of the lecturer's bilingualism is a topic change. It was also a dominant factor in conducting bilingualism. What happened here was a change of discussion topic. In which the lecturer wanted to make another type of conversation. In this example, she discussed about one student at the first time. Then, she alternated to another student. And finally she back to the first topic. Bilingualism for topic shift is a relatively frequent phenomenon in the classroom as instructions are usually carried out in the students' mother tongue. The switch of this kind signifies that the lecturer considered the use of first language as a compulsory means of explaining rules of the foreign language. Here is the example of the lecturer's conversation.

Example 9:

L: so, it depends on the context. Sayimah, you have many ideas to speak up. My mind got blank.

I have many ideas. What should I talk? Are you ok with your brain? Siapa itu

S: Nuriman miss

L: ob ya, Nuriman sorry. And than, ke sayimah, kembali ke sayimah back to Sayimah. I ask you to think and speak up. So, submit your brain, pick your brain. So, ada apa denganmu, kenapa harus menghilang? because of your teacher or your self.

Related to the text above, the words Siapa itu? and ke sayimah, kembali ke sayimah are the kinds of a topic change which were alternated by the lecturer. She did it to make the students understand about the change of discussion. This reason can be proved in interviewing transcript of the lecturer. 
When I change the topic or something discussed, I used bahasa to make the students understand about the change of discussion (interview).

\section{(3) Policy of institution}

The next factor is policy of institution or English department. Commonly the institution gives a rule or recommendation to the lecturer to speak full English or only $75 \%$ and Bahasa or the first language for the rest. In this department related to the lecturer teaches English, it is allowed for her to use first language or second language in EFL classroom. Therefore, she sometimes alternates her language from English to Bahasa or vice versa and even to vernacular language, which is madura. The following example is the short utterance related to the factor in policy of institution or English department. In conducting the data, the researcher interviewed the lecturer.

My institution allows the lecturer to use Bahasa in EFL classroom. We do not have to speak full in English. Even though we are English department basically, but the reason is about the students are able to achieve the lecturer's meant in teaching learning process clearly (interview).

\section{(4) Attendance}

And final factor dealing with the lecturer's bilingualism is personal factor dealing with attendance. When the lecturer applied English in her utterance, one of student entered the class. She was late. Then, she greeted to the lecturer and the class by using Bahasa. The word was assalamu'alaikum. This word is usually applied by the moslem students when they come to the class. For that situation, when the lecturer heard her greeting, finally the lecturer answered the word by saying wa'alaikumussalam. The lecturer changed her language from English to Bahasa in order to reply the student's greeting.

\section{d. Linguistibilingualism form of bilingualism}

In this research, the researcher not only investigated the form, function, and factor of bilingualism, but he also described the linguistibilingualism aspect of bilingualism. It deals with the word, phrase, and sentence. From the observation related to the lecturer's bilingualism, the researcher found the pattern of the lecturer's bilingualism as follow.

\section{(1) Word}

The lecturers often used the form word in applying bilingualism. It happened when she wanted to translate the word. For example, this utterance: menjalankan? Ok, undertake is menjalankan. The example indicates the word pattern of linguistibilingualism aspects in the lecturer's BILINGUALISM.

(2) Phrase.

(3) It sometimes applied by the lecturer to show more than one word in switching the language.

The data found is just give it body, I know, I know. And than for the language vocabnya asing miss. The alternated utterance of vocabnya asing miss can be categorized as a phrase.

(4) Sentence.

During the teaching learning process in EFL classroom, the lecturer's in certain case used a sentence in switching the language. The following example shows the sentence pattern of the lecturer's Bilingualism.

Example 10:

L: Now goes to Nuriman. Why does every single person use different vocab? jadi setiap orang menggunakan vocab yang berbeda. Sometimes we use scare, sometimes we use afraid.

The text above indicates that the lecturer used a sentence form when she conducted the switching the language from English to Bahasa. It was happened because she wanted to explain the whole part or the complete thing in that text. Another description of linguistibilingualism aspect used by the lecturer was also taken from the data interview. It showed that the lecturer used all of the linguistibilingualism aspect (word, phrase, and 
sentence) in inserting different language. She cited that it depended on the situation and condition or topic of the class and also dealing with the students' comprehension. 'T usually insert word, phrase, and sentence. As I remember, it depends on the situation, condition or topic, and also with the students' understanding".

\section{e. Frequency of bilingualism}

From the observation, it was found that the lecturer always applied bilingualism in EFL classroom. In the first observation, the researcher found 26 times bilingualism inserted by the lecturer during the teaching learning process, and the second observation she conducted the alternating language for about 12 times. While in the third observation, the lecturer applied for about 23 times Bilingualism. The researcher also took the data from students' and lecturer's questionnaire.

He conducted questionnaire to the students to get specific information and also to cross check with the data in observation related to the lecturer's frequency of bilingualism in EFL classroom. There were 26 students participated in this activity. The researcher classified frequency in three terms; those are seldom, often, and always. From the questionnaire was found that 4 students said that the lecturer seldom to apply bilingualism during the teaching learning process, 8 students agreed to say that their lecturer often to change the language, and 14 students strongly agreed that the lecturer always alternated her language. To support this data, the researcher also interviewed the students and the lecturer. The students said that their lecturer often used bilingualism and, in another situation, she always changed their language from English to Bahasa during EFL classroom. It also dealt with the lecturer statement that the she always alternates her language when she wanted to explain more the material and make the students easier in understanding the word meaning or what she meant. And in another time, she used it to clarify her words during the teaching learning process.

From the findings, the researcher found that most of students during the teaching and learning process interacted with the lecturer's conversation when the lecturer alternated her language from English to Bahasa. In another case the researcher also found that some students were quite difficult to receive the language or instruction from the lecturer when she always used English in EFL classroom.

From the data the researcher identifies the implication of bilingualism to students' speaking. The implication is about interact and apply the lecturer' utterance. It can be said this implication related to the students' understanding of the word meaning in speaking.

Second implication from the observation data is about students' comprehension in a certain word, such as compounding. The lecturer used bilingualism to explain the meaning of the word. By using Bahasa, the students were easier to understand the lecturer statement. In this case, the students knew what the lecturer' uttered and finally they could know the meaning of the word.

The next data dealing with the implication of bilingualism to the students' achievement in speaking is interview. The researcher interviewed the lecturer and the students. The data shows that the students understood the instruction, explanation, and another thing related to the teaching and learning process if the lecturer conducted bilingualism in EFL classroom. The process of teaching would not run well if they were not able to understand the lecturer's instruction. And finally, in applying bilingualism they can do what the lecturer meant clearly and comprehensively. In another case they got problem if the lecturer used English only during the class. So, the lecturer cited that bilingualism had really positive implication to the students' speaking achievement.

The third data related to the implication of bilingualism is questionnaire. From the data of questionnaire shows that most of students strongly agreed with the alternating language in the EFL classroom, whether from the lecturer's or students' bilingualism. Because, it had positive implication to their activity and speaking in the class. To support the data, the researcher also gave questionnaire to the lecturer. The lecturer argued that she strongly agreed with the bilingualism 
in EFL classroom because it had a good advantage to the students' speaking ability. Ferguson's (2003) review of the literature on classroom functions of bilingualism in post-colonial context, as this provides a succinct summary of the above mentioned functions of bilingualism in the educational context. Ferguson (2003) clusters the implication of bilingualism into three broad categories, namely:

a) bilingualism for curriculum access. Here bilingualism is used to help learners to understand the subject matter of the lesson;

b) bilingualism for classroom management discourse, for example, to motivate, discipline or praise learners, to deal with late-comers and disruptions, to gain and keep learners' attention or to encourage classroom participation;

c) bilingualism for interpersonal relations. According to Ferguson (2003: 43), the classroom in not merely a place of learning; it is also a "social and affective environment in its own right".

\section{REFERENCES}

Allwright, Dick and Kathleen M. Bailey. (1991). Focus on the language classroom. An introduction to classroom research for language teachers. Cambridge: Cambridge University Press.

Auer, Peter. (1998). Introduction: Bilingual Conversation Revisited. In P. Auer (eds.). Code-switching in conversation: Language, interaction and identity. London: Routledge. 1-24.

Brown, Douglas H. (2004). Language Assessment Principle and Classroom Practices. San Fransisco State University.

Chaer, Abdul. (2004). Sosiolinguistik. Jakarta: PT. Asdi Mahastya

Chaudron, Craig. (1988). Second language classrooms: Research on teaching and learning. Cambridge: Cambridge University Press.

Grosjean, Francois. (1982). Life with two Languages: An introduction to bilingualism. Cambridge, Massachusetts: Harvard University Press.

Macaro, Ernesto. (2001). Analysing Student Teachers' Codeswitching in Foreign Language Classrooms: Theories and Decision Making. The Modern Language Journal. Vol. 85, No 4, 531-548.

Myers-Scotton, Carrol. (2006). An introduction to bilingualsm. Oxford: Blackwell Publishing Ltd.

Richards, Jack C. (2002). Methodology in language teaching. Cambridge: Cambrige University Press.

Romaine, Suzanne. (1995). Bilingualism. 2nd edition. Oxford: Blackwell.

Soderberg, Arnfast, Juni and J. Normann Jorgensen. (2003). Code-switching as a Communication, Learning, and Social Negotiation Strategy in First year Learners of Danish. International Journal of Applied Linguistics. Vol. 13, No 1, 23-53.

Thomason, Sarah (Eds.). (2010). The handbook of language contact. Oxford: Blackwell Publishing Ltd.

Wardhaugh, Ronald. (1990). An Introduction to Sociolinguistics. Cambridge: Cambrige University Press.

Winford, Donald. (2003). An introduction to contact linguistics. Malden: Blackwell Publishing Ltd.

Yule, George. (1996). Pragmatics. New York: Oxford University Press.

Yule, George. (2010). The Study of Language. New York: Cambridge University Press. 